\title{
GRAPHITE FURNACE ATOMIC ABSORPTION SPECTROPHOTOMETRY SEBAGAI METODE ANALISIS LOGAM BERAT
}

\author{
Oleh \\ Fitri Budiyanto ${ }^{1)}$
}

\begin{abstract}
GRAPHITE FURNACE ATOMIC ABSORPRION SPECTROPHOTOMETRY AS A METHOD FOR ANALYZING HEAVY METAL. Heavy metal, mostly present in a (ultra) trace-level, becomes one of the hazardous pollutants due to its toxicity, bioaccumulative, biomagnificative characters. Conducting a micro analysis of these trace-level pollutants, a sensitive instrument and method are strongly recommended. Graphite Furnace Atomic Absorption Spectrophotometer (GFAAS) offers a solution for the challenge. It uses the principle of light emission absorption by nascent atom cloud from the metals. The analysis has been developed in three stages of the tube heating programs, i.e. drying, ashing and than atomizing element at $3000{ }^{\circ} \mathrm{C}$. Since the injected sample is almost completely atomized, the sensitivity of GFAAS is extremely high and this value is covering up the disadvantages of the other analyses. Therefore, the GFAAS analysis is suitable for ultra-trace analysis of ultra-trace pollutant like heavy metals in environment.
\end{abstract}

\section{PENDAHULUAN}

Logam berat merupakan salah satu jenis bahan pencemar yang ada di lingkungan (Zhao et al., 2012). Kebutuhan atas analisis logam berat secara akurat mendorong pengembangan peralatan analisis (Tokman et al., 2004). Saat ini, analisis serapan atom (atomic absorption) menjadi salah satu metode dalam analisis logam skala mikro (Jahromi et al., 2007). Analisis serapan atom menggunakan prinsip penyerapan cahaya pada panjang gelombang tertentu oleh logam yang telah teratomkan (Beaty \& Kerber, 1993). Berbagai macam keunggulan didapatkan dari analisis ini diantaranya adalah sen- sitivitas tinggi, keakuratan analisis yang tinggi, gangguan saat pengukuran relatif kecil dan cara pengoperasian yang mudah (Liu \& Liang, 2008). Dua jenis analisis serapan atom dikembangkan hingga saat ini yaitu spektrofotometer serapan atom menggunakan nyala (Flame Atomic Absorption Spectrophotometer/ FAAS) dan spektrofotometer serapan atom menggunakan pembakar grafit (Graphite Furnace Atomic Absorption Spectrophotometer GFAAS) (Beaty \& Kerber, 1993).

GFAAS memiliki prinsip kerja yang sama dengan FAAS, akan tetapi metode pengatoman logam yang digunakan

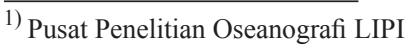


berbeda. GFAAS menggunakan pembakar yang terbuat dari grafit, sedangkan FAAS menggunakan nyala api (Evans et al., 1993). Grafit yang digunakan dalam GFAAS berbentuk silinder yang tersambung dengan elektroda di kedua ujungnya. GFAAS memiliki sensitivitas dan limit deteksi yang 20-1000 kali lebih baik dari FAAS. Perbedaan sensitivitas ini disebabkan oleh perbedaan densitas atom selama pengukuran yang terbentuk. Meskipun demikian, tingginya sensitivitas GFAAS memberikan dampak negatif yaitu tingginya gangguan saat analisis, penyiapan sampel yang lama dan waktu analisis yang relatif lama dibandingkan FAAS (Beaty \& Kerber, 1993).

GFAAS ini baik untuk analisa kuantitas mikro dari aluminium, antimoni, arsen, barium, berilium, kadmium, kromium, kobalt, besi, timbal, mangan, molibdenum, nikel, selenium, perak dan tin. Metode ini dapat pula digunakan untuk analisis bismuth, gallium, germanium, emas, indium, mercury, tellurium, thallium dan vanadium, tetapi presisi dan akurasi yang didapatkan kurang dibandingkan FAAS (Beaty \& Kerber, 1993). Belum banyak penelusuran tentang pengoperasian dan prinsip GFAAS di Indonesia. Oleh karena itu, tulisan ini dimaksudkan untuk memberikan ulasan mengenai prinsip kerja dari GFAAS.

\section{PRINSIP SPEKTROFOTOMETER SERAPAN ATOM}

\section{Atom yang menyerap cahaya}

Spektrofotometer serapan atom menggunakan prinsip penyerapan panjang gelombang cahaya oleh atom (Donega \& Burgess, 1968). Berdasarkan keadaannya, atom diklasifikasikan dalam dua kategori: atom yang memiliki energi rendah dan tinggi. Keadaan atom dalam energi rendah disebut ground state dan dalam energi tinggi disebut excited state. Ketika atom berada dalam keadaan ground state, maka, atom akan menyerap energi dari luar, dan menjadi excited state. Excited state ini akan bergantung pada jumlah energi yang diterima (Beaty \& Kerber, 1993).

Perbedaan antara energi ground state dan excited state tergantung pada jenis unsur dan panjang gelombang dari cahaya yang diserap. Spektrofotometer serapan atom menggunakan sumber cahaya dari lampu jenis Hollow Cathode Lamp (HCL), dimana HCL ini dapat memancarkan cahaya dengan panjang gelombang yang sesuai dengan elemen yang akan diukur. Ketika cahaya dalam intensitas tertentu dipancarkan ke atom dalam ground state, cahaya tersebut diserap oleh atom dan kecepatan penyerapannya dipengaruhi oleh kepadatan atom (Gambar 1) (Beaty \& Kerber, 1993). 


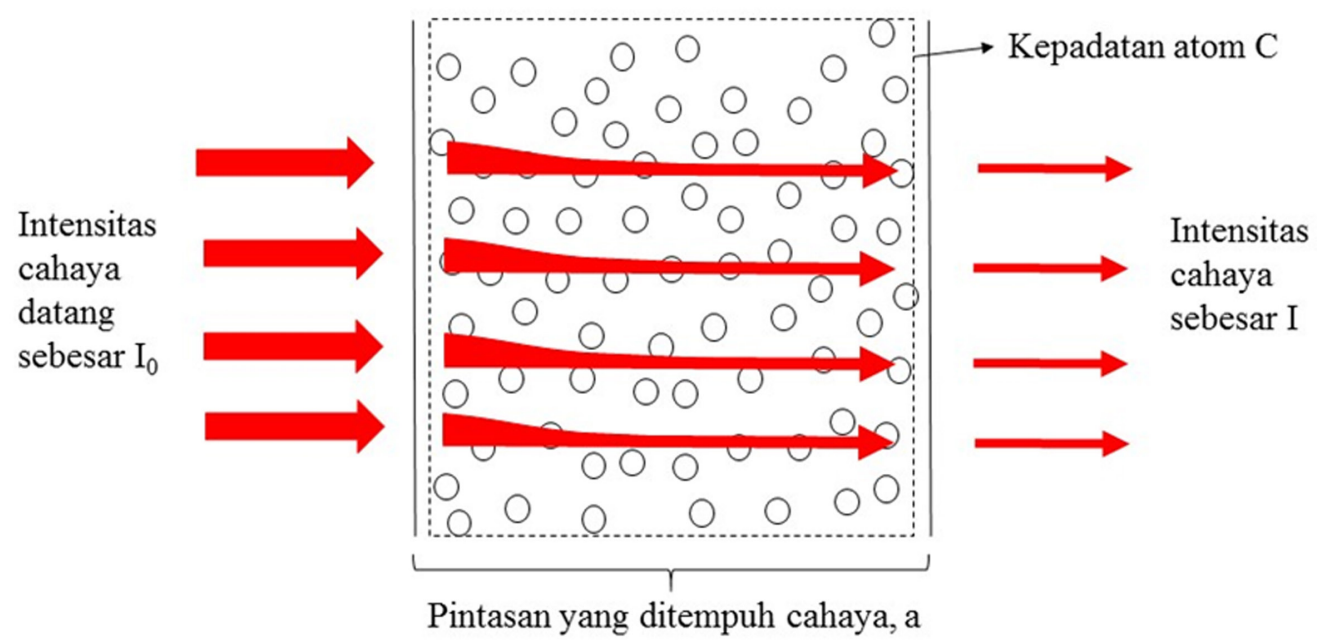

Gambar 1. Prinsip Absorbsi cahaya oleh atom (Beaty \& Kerber, 1993).

Ketika cahaya dengan intensitas $\mathrm{I}_{0}$ melalui atom dengan kepadatan $\mathrm{C}$, sejauh panjang a, seperti ditunjukkan pada Gambar 1, cahaya diserap dan intensitasnya turun menjadi I. Formula tersebut dibawah ini merupakan perbandingan antara I dan $\mathrm{I}_{0}$.

$$
\begin{gathered}
I=I_{0} x e^{-k \cdot a \cdot c} I=I_{0} x e^{-k \cdot a \cdot c} \\
\text { atau }-\log \frac{I}{I_{0}}=k \cdot a \cdot c
\end{gathered}
$$

Dimana $\mathrm{k}$ adalah tetapan proporsional, a adalah ketebalan medium (kumpulan atom yang harus dilalui), dan c adalah konsentrasi dari zat yang diukur. Formula di atas disebut hukum LambertBeer's, dan nilai $-\log \frac{I}{I_{0}}$ merupakan nilai absorbansi. Dari formula tersebut diindikasikan bahwa nilai serapan cahaya proporsional dengan kepadatan C (Beaty \& Kerber, 1993). Prinsip ini berlaku untuk semua jenis spektrofotometer. Dalam spekrofotomer serapan atom, yang menyerap cahaya adalah logam yang teratomkan.

\section{Metode atomisasi logam}

Prinsip Lambert-Beer's disebutkan di atas hanya berlaku untuk keadaan "atom bebas". Atom bebas berarti atom tersebut tidak terikat dengan atom lain. Akan tetapi, atom-atom yang ada dalam sampel tidak berada dalam kondisi bebas tetapi berikatan dengan unsur lain yang kemudian membentuk molekul (Betts, 2017). Sebagai contoh, sodium dalam air laut bergabung dengan klorida membentuk molekul $\mathrm{NaCl}$ (Sodium klorida). Proses serapan tidak dapat dilakukan untuk sampel yang berbentuk molekul karena molekul tidak menyerap cahaya. Molekul-molekul harus dipecah untuk membentuk atom bebas. Proses ini disebut atomisasi dan metode atomisasi yang paling populer adalah peruraian dengan panas. Dalam spektrofotometer serapan atom, metode pemanasan ini dikembangkan dalam bentuk pemanasan dengan nyala api (flame method) dan listrik (electric furnace) (Beaty \& Kerber, 1993). Contoh FAAS dan GFAAS ditunjukkan Gambar 2. 
Metode atomisasi menggunakan nyala api merupakan metode yang paling banyak digunakan. Ada empat standar gas yang digunakan sebagai bahan bakar yaitu udara-asetilen, nitrous oxide-asetilen, udara-hidrogen dan argon-hidrogen. Akan tetapi, kelemahan yang paling utama untuk metode atomisasi ini adalah atomisasi sampel yang hanya $1 / 10$ dari jumlah total sampel yang telah masuk dalam nyala api dan 9/10 lainnya terbuang. Oleh karena itu, efisiensi dari atomisasi terlalu rendah, dan sensitivitasnya tidak terlalu tinggi (Beaty \& Kerber, 1993).

GFAAS menggunakan grafit berbentuk silinder yang memiliki sensitivitas 10 sampai 200 kali dibanding atomisasi menggunakan nyala api. Dalam prosesnya, setelah sampel dimasukkan dalam grafit, pemanasan untuk proses atomisasi terbagi dalam 3 tahap. Pertama adalah tahap pengeringan dimana grafit dipanaskan sampai sekitar $100^{\circ} \mathrm{C}$ dan air dalam sampel menguap secara sempurna. Tahap kedua adalah pengabuan (ashing stage) dimana grafit dipanaskan dari $400^{\circ} \mathrm{C}$ sampai $1000^{\circ} \mathrm{C}$, sehingga semua zat organik terurai dan menguap. Terakhir, tahap atomisasi, pemanasan dilakukan dari $1400^{\circ} \mathrm{C}$ sampai $3000^{\circ} \mathrm{C}$ dan logam yang tertinggal dalam silinder teratomisasi. Untuk mencegah pembakaran berlebih dalam grafit selama pemanasan, maka oksigen dari udara dan grafit dialiri gas inert baik di dalam maupun di luar seperti Gambar 3 (Beaty \& Kerber, 1993).

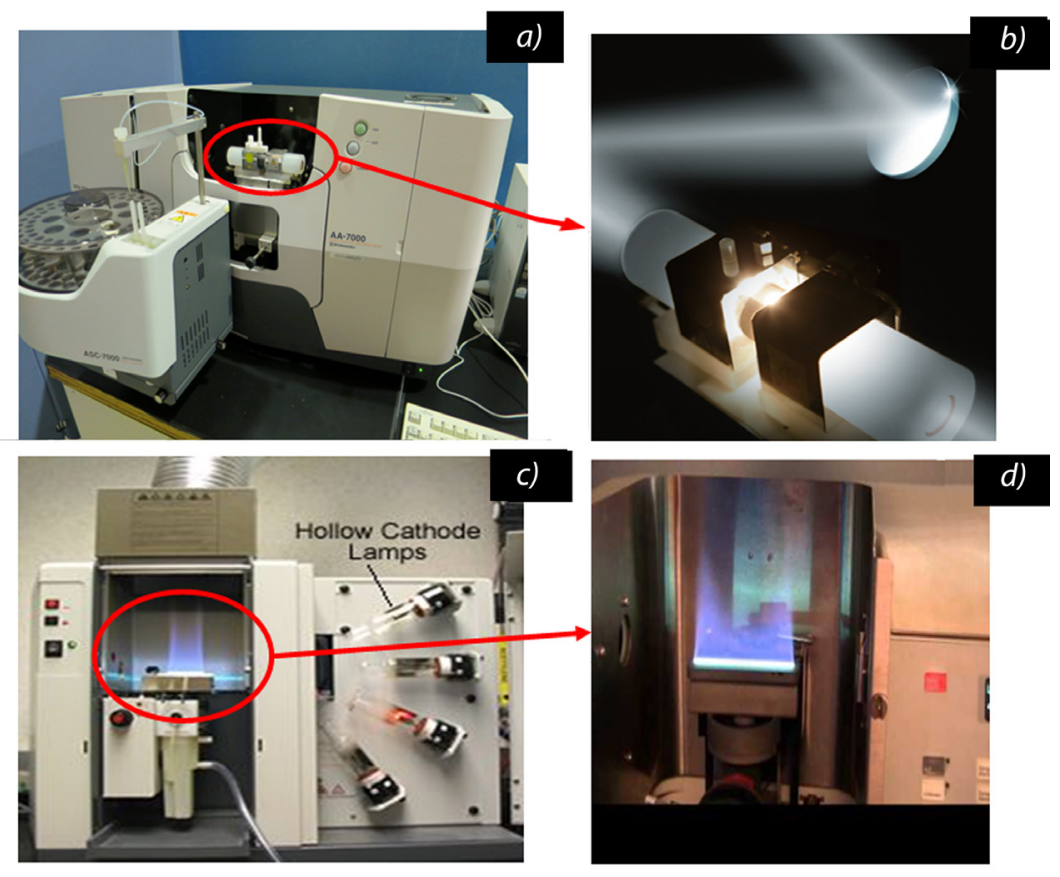

Gambar 2. Spektrofotometer serapan atom: (a) GFAAS secara utuh; (b) skema pembakar grafit yang sedang beroperasi; (c) FAAS secara utuh; (d) nyala api dari FAAS (Shimadzu corporation, 2017; Betts, 2017). 


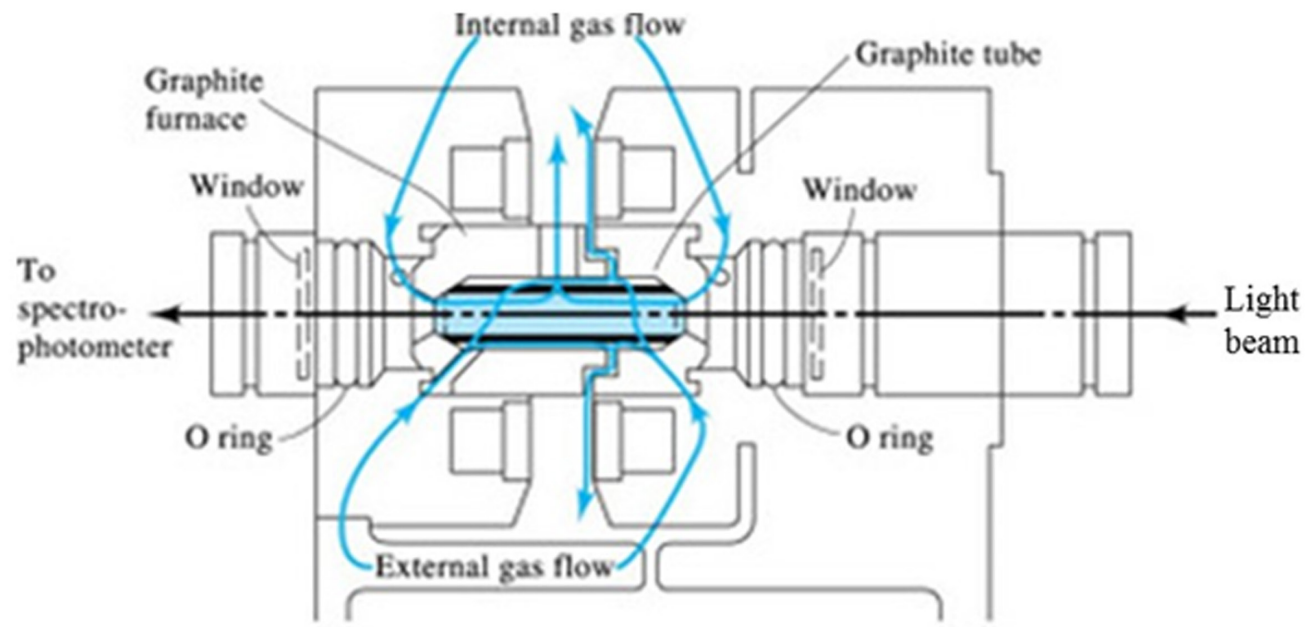

(a)

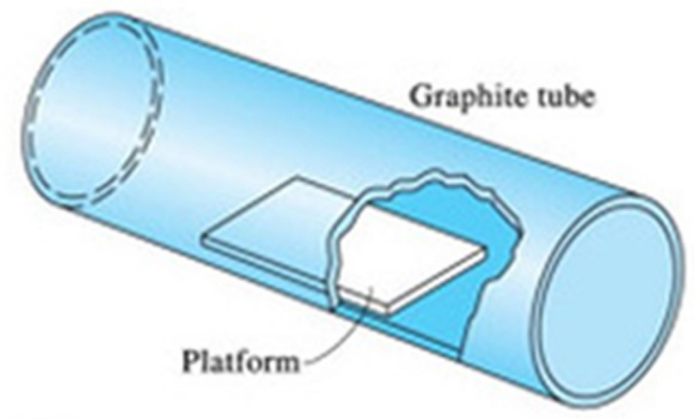

(b)

Gambar 3. Skema pembakar grafit: (a) aliran gas inert dalam pembakar grafit, (b) Silinder grafit (Gigante et al., 2012).

\section{KOMPONEN GFAAS}

Spektrofotometer serapan atom terdiri atas sumber cahaya yang memancarkan spektrum unsur menggunakan hollow cathode lamp atau electrodeless discharge lamp, peralatan untuk mengatomkan sampel, alat isolasi spektrum (monochromator atau filter dan celah pengatur) dan detektor fotoelektrik, serta peralatan pengukuran (Beaty \& Kerber, 1993). a. Sumber cahaya menggunakan hollow chatode lamp (HCL) (Gambar 4), atau electrodeless discharge lamp (EDL). Ada dua jenis HCL yaitu HCL unsur tunggal dan HCL multi-unsur. HCL multi-unsur biasanya memberikan sensitivitas yang rendah, sedangkan EDL memerlukan waktu yang lebih lama untuk pemanasan, dan waktu yang lebih lama untuk stabil sehingga lebih disukai HCL unsur tunggal (Beaty \& Kerber, 1993). 


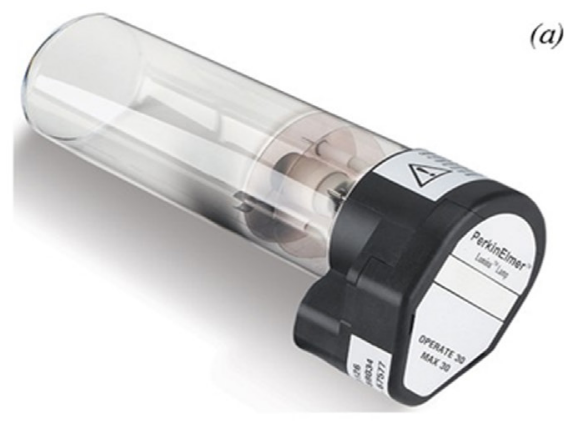
unsur yang sama dengan unsur yang akan diuji

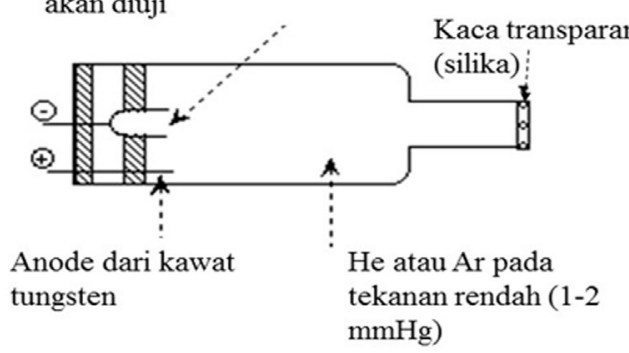

Gambar 4. Hollow Cathode Lamp (HCL): (a) HCL untuk unsur Mangan (Mn) yang diproduksi oleh Perkin Elmer (Perkinelmer, 2017); (b) skema dari HCL (New Mexico State University, 2006)

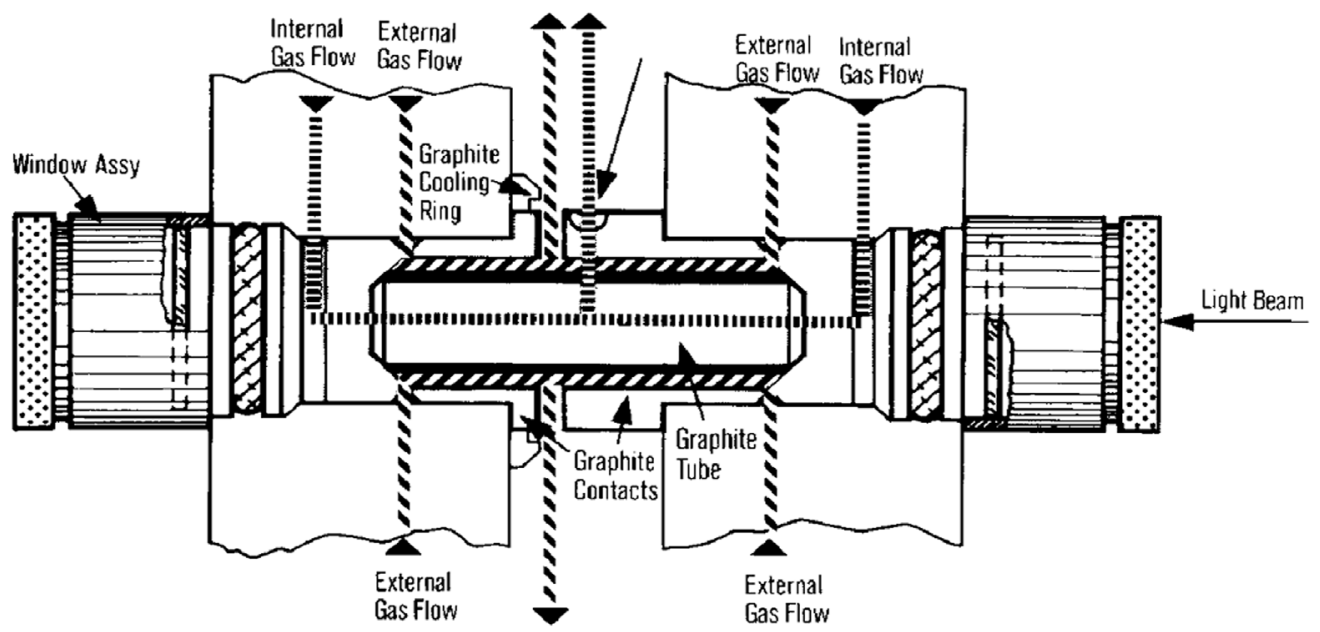

Gambar 5. Skema pemakar grafit yang diproduksi oleh Perkin Elmer (Beaty \& Kerber, 1993).

b. Pembakar grafit merupakan sebuah set alat elektronik yang terdiri atas kontrol, silinder grafit dan wadah yang menyangga silinder grafit, sementara pendingin yang digunakan adalah air suling (Gambar 5).

c. Monochromator digunakan untuk memisahkan spektrum cahaya. Cahaya kuat yang dipancarkan langsung melewati silinder grafit akan merusak detektor atau mengurangi akurasi, sehingga dipasang monokromator antara atomizer dengan detektor.

d. Readout/detector digunakan untuk membaca spektral cahaya.

\section{GANGGUAN DI GFAAS}

Gangguan yang umum terjadi dalam GFAAS dapat dikelompokkan dalam dua bentuk, yaitu gangguan spektrofotometrik dan gangguan fisik. Gangguan spektrofotometrik terjadi karena garis-garis spektra 
tidak dapat dipisahkan secara sempurna, atau ketika garis spektra yang digunakan untuk analisis diserap oleh unsur selain unsur target. Gangguan fisik terjadi ketika sampel yang dianalisis kurang memenuhi standar uji, seperti viskositas dari larutan sampel ataupun tegangan muka yang terlalu tinggi. Tingginya viskositas ini menyebabkan sampel tidak terdistribusi dengan baik di dalam silinder grafit (Beaty \& Kerber, 1993).

\section{Metode koreksi gangguan}

Gangguan spektrofotometrik pada prinsipnya disebabkan oleh kegagalan pemisahan spektrum cahaya ataupun absorpsi spektrum cahaya oleh molekul. Kegagalan pemisahan spektrum cahaya disebabkan ketika garis spektral yang digunakan untuk pengukuran dan garis spektral lain yang berdekatan tumpang tindih satu sama lain. Gangguan tipe ini tidak umum dan dapat dihindari dengan memilih garis spektral yang tidak menunjukkan interferensi. Adapun gangguan absorbansi spektrum cahaya oleh molekul disebabkan karena absorbsi cahaya dan pemencaran oleh molekul yang tidak teratomkan. Pemencaran cahaya terjadi ketika partikel padat melewati cahaya. Contoh fenomena ini terjadi ketika sampel dipanaskan dan uap terbentuk. Puncak pemencaran oleh uap meningkat bersamaan dengan penurunan panjang gelombang. Hal ini sering terjadi untuk pengukuran unsur dengan panjang gelombang kurang dari $250 \mathrm{~nm}$. Untuk menangani hal ini maka kondisi pemanasan diatur sedemikian rupa sehingga lebih banyak uap yang terbentuk pada tahap pengabuan dan mencegah uap terbentuk di tahap atomisasi. Kondisi fisik sampel menyebabkan gangguan fisik dalam pengukuran dimana difusi sampel dalam silinder grafit akan heterogen dan menyebabkan bias (Beaty \& Kerber, 1993).

\section{PEMILIHAN SILINDER GRAFIT}

Untuk pengukuran menggunakan GFAAS, pemilihan silinder grafit akan memengaruhi hasil analisis dan pemilihan ini berdasar jenis unsur dan sampel yang akan dianalisis. Tiga tipe silinder grafit yang saat ini sering digunakan yaitu: high density graphite tube (HDGT), pyrolitic coating graphite tube (PCGT) dan platform type graphite tube (PTGT) (Beaty \& Kerber, 1993).

\section{High Density Graphite Tube (HDGT)}

HDGT dibuat dari grafit asli (Gambar 6), dan paling banyak digunakan. HDGT digunakan untuk mengukur unsur yang memiliki temperatur atomisasi yang rendah, sebagai contoh: $\mathrm{Cd}, \mathrm{Pb}, \mathrm{Na}, \mathrm{K}$, $\mathrm{Zn}$ dan Mg. Tipe silinder grafit ini juga digunakan untuk sensitivitas pengukuran yang rendah pada kasus konsentrasi sampel yang tinggi. Sebagai contoh, unsur Al, Fe dan $\mathrm{Cu}$ dapat diukur sampai 1 ppb jika PCGT digunakan, tetapi sensitivitas pengukuran akan turun pada level 100 ppb bila HDGT digunakan (catatan: semakin tinggi level konsentrasi yang dapat terukur berarti sensitivitas makin rendah) (Beaty \& Kerber, 1993). 

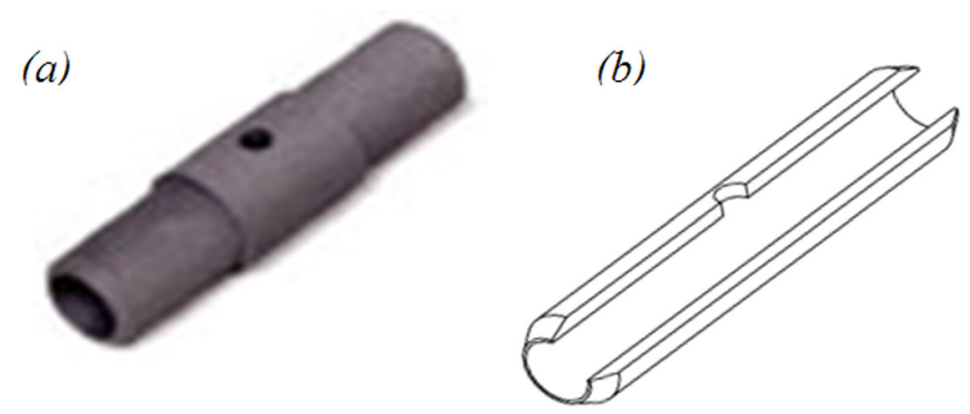

Gambar 6. High Density Graphite Tube yang dijual di pasar: (a) penampakan silinder asli; (b) skema penampang (Shimadzu Corporation, 2017).
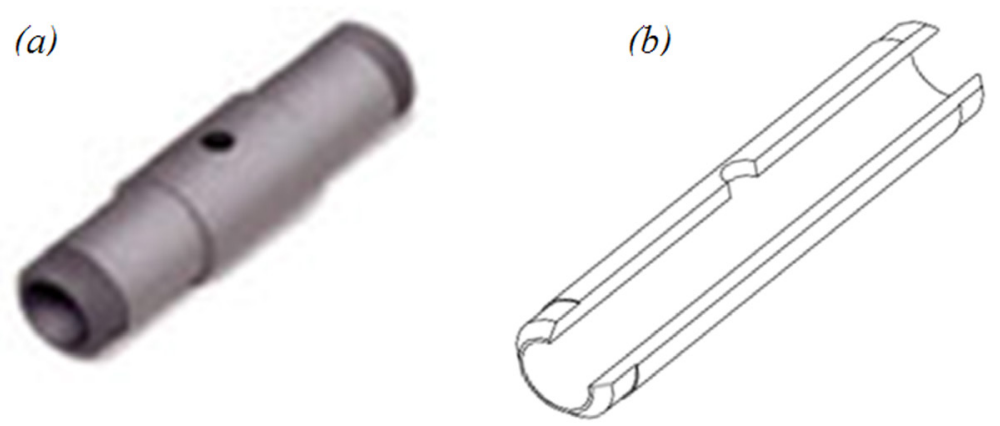

Gambar 7. Pyro-Coated Graphite Tube yang dijual di pasar: (a) penampakan silinder asli; (b) skema penampang (Shimadzu Corporation, 2017).

\section{Pyrolitic Coated Graphite Tube (PCGT)}

Secara umum, PCGT digunakan untuk analisis unsur-unsur yang dapat bereaksi dengan karbon dari silinder grafit, sebagai contoh unsur $\mathrm{Ni}, \mathrm{Ca}, \mathrm{Ti}, \mathrm{Si}$, $\mathrm{V}$ dan Mo. Desain PCGT sama dengan HDGT hanya permukaan silinder yang berbeda dimana PCGT dilapisi lapisan pirolitik (Gambar 7). Pada HDGT, sampel mudah merembes pada grafit, dan mengakibatkan luas kontak yang besar antara sampel dengan karbon, sedangkan pada PCGT, didapatkan luas kontak yang lebih kecil yang dapat menekan pembentukan karbon, sehingga sensitivitas meningkat. Sebagai catatan, PCGT sangat mudah terpengaruh oleh kandungan asam dari sampel dan heterogenitas distribusi sampel dalam silinder grafit mudah terjadi sehingga reproduksibilitas pengukuran lebih buruk dibandingkan dengan HDGT. Sensitivitas PCGT sangat dipengaruhi oleh konsentrasi asam dalam sampel dibanding dengan PTGT dan HDGT (Beaty \& Kerber, 1993).

\section{Platform Type Graphite Tube (PTGT)}

Pada metode GFAAS, silinder grafit dipanaskan pertama kali di dindingnya. Pada silinder yang normal, sampel dipanaskan dan diatomkan seiring dengan pemanasan dinding tube. Pada PTGT, 
sampel diatomkan setelah temperatur di seluruh silinder mencapai temperatur atomisasi. PTGT didesain memiliki platform di diameter silindernya (Gambar 8). Silinder grafit ini efektif digunakan untuk sampel dengan matriks kompleks, seperti sampel biologi, limbah dan air laut (Beaty \& Kerber, 1993).

\section{SENSITIVITAS, LEVEL DETEKSI DAN KONSENTRASI OPTIMUM}

Estimasi level deteksi dan konsentrasi optimum pengukuran menggunakan GFAAS dirangkum pada Tabel 1. Nilai tersebut dapat berubah akibat bentuk kimia unsur yang akan diukur, komposisi sampel, atau kondisi peralatan. Untuk setiap pengukuran, sensitivitas ukur dapat dinaikkan dengan menggunakan volume sampel yang besar atau dengan mengurangi kecepatan aliran gas inert. Akan tetapi teknik-teknik ini akan meningkatkan potensi gangguan. Sensitivitas dapat dikurangi dengan mengencerkan sampel, mengurangi volume sampel, menaikkan kecepatan aliran gas inert atau menggunakan panjang gelombang yang kurang sensitif. Penggunaan Argon, sebagai pengganti Nitrogen, sebagai gas inert secara garis besar akan menaikkan sensitivitas dan reproduksibilitas. Campuran hidrogen dengan gas inert dapat menekan gangguan kimia dan menaikkan sensitivitas dengan berperan sebagai agen pereduksi, yang kemudian akan menghasilkan lebih banyak atom dalam kondisi ground state (Beaty \& Kerber, 1993).
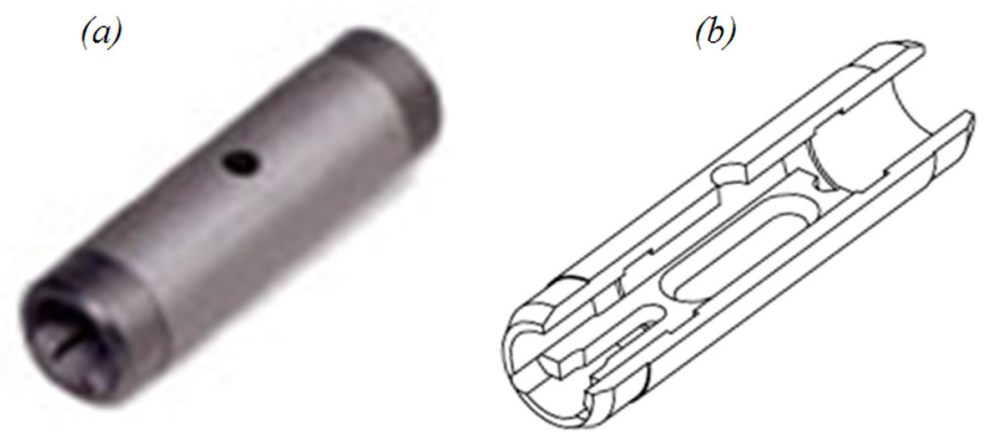

Gambar 8. Platform Type Graphite Tube yang dijual di pasar: (a) penampakan silinder asli; (b) skema penampang (Shimadzu Corporation, 2017). 
Tabel 1. Level Deteksi dan Kisaran Konsentrasi untuk Graphite Furnace Atomic Absorption Spectrophotometry

\begin{tabular}{cccc}
\hline Unsur & $\begin{array}{c}\text { Panjang gelombang } \\
(\mathrm{nm})\end{array}$ & $\begin{array}{c}\text { Level deteksi } \\
(\mu \mathrm{g} / \mathrm{L})\end{array}$ & $\begin{array}{c}\text { Konsentrasi optimum } \\
(\mu \mathrm{g} / \mathrm{L})\end{array}$ \\
\hline $\mathrm{Al}$ & 309,3 & 3 & $20-200$ \\
$\mathrm{Sb}$ & 217,6 & 3 & $20-300$ \\
$\mathrm{As}$ & 193,7 & 1 & $5-100$ \\
$\mathrm{Ba}$ & 553,6 & 2 & $10-200$ \\
$\mathrm{Be}$ & 234,9 & 0,2 & $1-30$ \\
$\mathrm{Cd}$ & 228,8 & 0,1 & $0,5-10$ \\
$\mathrm{Cr}$ & 357,9 & 2 & $5-100$ \\
$\mathrm{Co}$ & 240,7 & 1 & $5-100$ \\
$\mathrm{Cu}$ & 324,7 & 1 & $5-100$ \\
$\mathrm{Fe}$ & 248,3 & 1 & $5-100$ \\
$\mathrm{~Pb}$ & 283,3 & 1 & $5-100$ \\
$\mathrm{Mn}$ & 279,5 & 0,2 & $1-30$ \\
$\mathrm{Mo}$ & 313,3 & 1 & $3-60$ \\
$\mathrm{Ni}$ & 232,0 & 1 & $5-100$ \\
$\mathrm{Se}$ & 196,0 & 2 & $5-100$ \\
$\mathrm{Ag}$ & 328,1 & 0,2 & $1-25$ \\
$\mathrm{Sn}$ & 224,6 & 5 & $20-300$ \\
\hline
\end{tabular}

\section{PENUTUP}

Metode analisis logam berat menggunakan GFAAS digunakan untuk analisis logam berat skala mikro, dan masih dikembangkan sampai saat ini untuk analisis skala sangat kecil (ultra-trace). Dalam prakteknya, untuk mendapatkan hasil pengukuran yang dapat diterima, analisis logam berat dengan GFAAS ini biasanya dikolaborasikan dengan pretreatment sampel uji, seperti pemekatan sampel menggunakan cloud point extraction, pengendapan, ekstraksi caircair, filtrasi menggunakan membran, ion-exchange, ataupun adsorpsi. Sampai saat ini, metode pretreatment sampel uji ini juga masih dikembangkan dan diteliti untuk berbagai jenis analisis logam berat. Sehingga, dari sisi instrumen maupun dari sisi analisis logam berat menggunakan GFAAS masih banyak ruang untuk dapat dikembangkan. 


\section{DAFTAR PUSTAKA}

Betts, T. 2017. Atomic spectroscopy [online]. https://www.kutztown.edu. Diakses pada tanggal 3 Mei 2017.

New Mexico State University. 2006. Hollow Cathode Lamps [online]. https://web.nmsu.edu. Diakses pada tanggal 3 Mei 2017.

Perkinelmer. 2017. Manganese (Mn) Lumina Hollow Cathode Lamp, diameter: $50 \mathrm{~mm}$ [online]. http://www.perkinelmer.com. Diakses pada tanggal 3 Mei 2017.

Shimadzu Corporation. 2017. AA-6880 Atomic Absorption Spectrophotometer [online]. http:// www.shimadzu.com. Diakses pada tanggal 3 Mei 2017.

Beaty, R. D. and J. D. Kerber. (1993). Concepts, Instrumentation and Techniques in Atomic Absorption Spectrophotometry, Second Edition, The Perkin-Elmer Corporation, Northwalk, US: $96 \mathrm{hlm}$.

Donega, H. M. and T. E. Burgess. 1968. US Patent No. 3591289: Atomic absorption sample cell: US Patent: $4 \mathrm{hlm}$.

Evans, D. W., D. K. Dodoo and P. J. Hanson. 1993. Trace Element Concentrations in Fish Livers : Implications of Variations with Fish Size. Marine Pollution Bulletin 26 (6): 329-334.
Jahromi, Z. E., A. Bidari, Y. Assadi, M. R. H. Milani and M. R. Jamali. 2007. Dispersive liquid-liquid microextraction combined with graphite furnace atomic absorption spectrometry. Ultra trace determination of cadmium in water samples. Analytica Chimica Acta 585 (2): 305311. http://doi.org/10.1016/j. aca.2007.01.007.

Gigante, G.E., S. Ridolfi, M.A. Floriano, E. Caponetti, L. Gontrani, R. Caminiti, M.L. Saladino, D.C. Martino, N. Schiavon, C.D. Barrocas and K. Chrysafis. 2012. Identification techniques II in Conservation Science for Cultural Heritage, SpringerVerlag Berlin Heidelberg: p. 91-161.

Liu, R. and P. Liang. 2008. Determination of trace lead in water samples by graphite furnace atomic absorption spectrometry after preconcentration with nanometer titanium dioxide immobilized on silica gel. Journal of Hazardous Materials 152(1): 166171. http://doi.org/10.1016/j. jhazmat.2007.06.081.

Tokman, N., S. Akman and C. Ozeroglu. 2004. Determination of lead, copper and manganese by graphite furnace atomic absorption spectrometry after separation/concentration using a water-soluble polymer. Talanta 63(3): 699-703. http://doi.org/10.1016/j.talanta.2003.12.018. 
Zhao, S., C. Feng, W. Quan, X. Chen, J. Niu and Z. Shen. 2012. Role of living environments in the accumulation characteristics of heavy metals in fishes and crabs in the Yangtze River Estuary, China. Marine Pollution Bulletin 64(6): 1163-1171. http://doi.org/10.1016/j.marpolbul.2012.03.023. 